\title{
Pengaruh Metode Stimulus Respon terhadap Daya Serap pada Pembelajaran Keterampilan Berbicara
}

\author{
M. Zulham1, Pancana Beta ${ }^{2}$ \\ Program Studi Pendidikan Guru Sekolah Dasar \\ Fakultas Keguruan dan Ilmu Pendidikan \\ Universitas Cokroaminoto Palopo \\ m.zulham92@yahoo.co.id ${ }^{1}$, pancanabeta.uncp@gmail.com²
}

\begin{abstract}
Abstrak
Penelitian ini bertujuan mengetahui: (1) Hasil daya serap siswa kelas VIII SMP Negeri 6 Palopo sebelum dan setelah diterapkan metode stimulus respon pada pembelajaran keterampilan berbicara, (2) peningkatan daya serap siswa kelas VIII SMP Negeri 6 Palopo setelah penerapan metode Stimulus Respon pada pembelajaran keterampilan berbicara. Satuan eksperimen adalah siswa kelas $\mathrm{VIII}_{\mathrm{B}}$ SMP Negeri 6 Palopo dengan jumlah siswa 32 orang yang dipilih dengan menggunakan teknik random sampling. Instrumen penelitian yang digunakan adalah tes hasil daya serap siswa. Pengumpulan data dilakukan dengan pemberian tes awal (pretest) dan tes akhir (posttest). Hasil penelitian menunjukkan bahwa (1) Hasil daya serap siswa kelas VIII SMP Negeri 6 Palopo sebelum diterapkan metode stimulus respon pada pembelajaran keterampilan berbicara berada pada kategori sangat rendah, (2) Hasil daya serap siswa kelas VIII SMP Negeri 6 Palopo setelah diterapkan metode stimulus respon pada pembelajaran keterampilan berbicara berada pada kategori sangat tinggi, (3) Terjadi peningkatan daya serap siswa kelas VIII SMP Negeri 6 Palopo setelah penerapan metode Stimulus Respon pada pembelajaran keterampilan berbicara. Sehingga dapat disimpulkan bahwa metode stimulus respon berpengaruh terhadap daya serap siswa kelas VIII SMP Negeri 6 Palopo pada pembelajaran keterampilan berbicara.
\end{abstract}

Kata kunci: Metode Stimulus Respon, Keterampilan Berbicara, Daya Serap

\section{Pendahuluan}

Pembelajaran Bahasa Indonesia merupakan salah satu materi pelajaran yang sangat penting di sekolah. Tujuan pembelajaran bahasa Indonesia adalah agar siswa memiliki kemampuan berbahasa Indonesia yang baik dan benar serta dapat menghayati bahasa dan sastra Indonesia sesuai dengan situasi dan tujuan berbahasa serta tingkat pengalaman siswa sekolah dasar. Akhadiah dkk. (1991: 1).

Pembelajaran merupakan upaya membelajarkan siswa Degeng (1989). Kegiatan pengupayaan ini akan mengakibatkan siswa dapat mempelajari sesuatu dengan cara efektif dan efisien. Upaya-upaya yang dilakukan dapat berupa analisis tujuan dan karakteristik studi dan siswa, analisis sumber belajar, menetapkan strategi pengorganisasian, isi pembelajaran, menetapkan strategi penyampaian pembelajaran, menetapkan strategi pengelolaan pembelajaran, dan menetapkan prosedur pengukuran hasil pembelajaran. Oleh karena itu, setiap pengajar harus memiliki keterampilan dalam memilih strategi pembelajaran untuk setiap jenis 
kegiatan pembelajaran. Dengan demikian, dengan memilih strategi pembelajaran yang tepat dalam setiap jenis kegiatan pembelajaran, diharapkan pencapaian tujuan belajar dapat terpenuhi. Gilstrap dan Martin (1975) juga menyatakan bahwa peran pengajar lebih erat kaitannya dengan keberhasilan pebelajar, terutama berkenaan dengan kemampuan pengajar dalam menetapkan strategi pembelajaran.

Belajar bahasa pada hakikatnya adalah belajar komunikasi. Oleh karena itu, pembelajaran bahasa diarahkan untuk meningkatkan kemampuan pebelajar dalam berkomunikasi, baik lisan maupun tulis (Depdikbud, 1995). Hal ini relevan dengan kurikulum 2004 bahwa kompetensi pebelajar bahasa diarahkan ke dalam empat sub aspek, yaitu membaca, berbicara, menyimak, dan mendengarkan.

Sedangkan tujuan pembelajaran bahasa, menurut Basiran (1999) adalah keterampilan komunikasi dalam berbagai konteks komunikasi. Kemampuan yang dikembangkan adalah daya tangkap makna, peran, daya tafsir, menilai, dan mengekspresikan diri dengan berbahasa. Kesemuanya itu dikelompokkan menjadi kebahasaan, pemahaman, dan penggunaan. Sementara itu, dalam kurikulum 2004 untuk SMA dan MA, disebutkan bahwa tujuan pembelajaran Bahasa dan Sastra Indonesia secara umum meliputi (1) siswa menghargai dan membanggakan Bahasa Indonesia sebagai bahasa persatuan (nasional) dan bahasa negara, (2) siswa memahami Bahasa Indonesia dari segi bentuk, makna, dan fungsi,serta menggunakannya dengan tepat dan kreatif untuk bermacam-macam tujuan, keperluan, dan keadaan, (3) siswa memiliki kemampuan menggunakan Bahasa Indonesia untuk meningkatkan kemampuan intelektual, kematangan emosional,dan kematangan sosial, (4) siswa memiliki disiplin dalam berpikir dan berbahasa (berbicara dan menulis), (5) siswa mampu menikmati dan memanfaatkan karya sastra untuk mengembangkan kepribadian, memperluas wawasan kehidupan, serta meningkatkan pengetahuan dan kemampuan berbahasa, dan (6) siswa menghargai dan membanggakan sastra Indonesia sebagai khazanah budaya dan intelektual manusia Indonesia.

Untuk mencapai tujuan di atas, pembelajaran bahasa harus mengetahui prinsip-prinsip belajar bahasa yang kemudian diwujudkan dalam kegiatan pembelajarannya, serta menjadikan aspek-aspek tersebut sebagai petunjuk dalam kegiatan pembelajarannya. Prinsip-prinsip belajar bahasa dapat disarikan sebagai berikut. Pebelajar akan belajar bahasa dengan baik bila (1) diperlakukan sebagai individu yang memiliki kebutuhan dan minat, (2) diberi kesempatan berapstisipasi dalam penggunaan bahasa secara komunikatif dalam berbagai macam aktivitas, (3) bila ia secara sengaja memfokuskan pembelajarannya kepada bentuk, keterampilan, dan strategi untuk mendukung proses pemerolehan bahasa, (4) ia disebarkan dalam data sosiokultural dan pengalaman langsung dengan budaya menjadi bagian dari bahasa sasaran, (5) jika menyadari akan peran dan hakikat bahasa dan budaya, (6) jika diberi umpan balik yang tepat menyangkut kemajuan mereka, dan (7) jika diberi kesempatan untuk mengatur pembelajaran mereka sendiri (Aminuddin, 1994). 
Thornike, salah seorang penganut paham behavioristik, menyatakan bahwa belajar merupakan peristiwa terbentuknya asosiasi-asosiasi antara peristiwaperistiwa yang disebut stimulus (S) dengan respon ( $R$ ) yang diberikan atas stimulus tersebut. Pernyataan Thorndike ini didasarkan pada hasil eksperimennya di laboratorium yang menggunakan beberapa jenis hewan seperti kucing, anjing, monyet, dan ayam. Menurutnya, dari berbagai situasi yang diberikan seekor hewan akan memberikan sejumlah respon, dan tindakan yang dapat terbentuk bergantung pada kekuatan keneksi atau ikatan-ikatan antara situasi dan respon tertentu. Kemudian ia menyimpulkan bahwa semua tingkah laku manusia baik pikiran maupun tindakan dapat dianalisis dalam bagian-bagian dari dua struktur yang sederhana, yaitu stimulus dan respon. Dengan demikian, menurut pandangan ini dasar terjadinya belajar adalah pembentukan asosiasi antara Stimulus dan Respon. Oleh karena itu, menurut Hudojo (dalam Asnaldi, 2008) teori Thondike ini disebut teori asosiasi.

Beberapa teori belajar dari psikologi behavioristik dikemukakakn oleh para psikolog behavioristik. Mereka ini sering disebut " Contemporary Behaviorists" atau jg disebut "S-R Psychologists". Mereka berpendapat bahwa tingkah laku manusia itu dikendalikan oleh ganjaran (reward) atau penguatan (reinforcement) dari lingkungan. Dengan demikian, dalam tingkah laku belajar terdapat jalinan yang erat antara reaksi-rekasi behavioral dengan stimulasinya. Belajar menurut psikologi behavioristik adalah suatu kontrol instrumental yang berasal dari lingkungan. Belajar tidaknya seseorang bergantung kepada faktorfaktor kondisional yang diberikan oleh lingkungan. Oleh karena itu, teori ini juga dikenal dengan teori conditioning.

Menurut Gutrie, setiap situasi belajar merupakan gabungan berbagai stimulus (dapat internal dan dapat eksternal) dan respon. Dalam situasi tertentu, banyak stimulus yang berasosiasi dengan banyak respon. Asosiasi tersebut, dapat benar dan dapat juga salah.

Ada tiga metode pengubahan tingkah laku menurut teori ini, yaitu :

a) Metode respon bertentangan. Misalnya saja, jika anak jijik terhadap sesuatu, sebutlah misalkan saja boneka, maka permainan anak yang disukai tersebut diletakkan di dekat boneka. Dengan meletakkan permainan di dekat boneka, dan ternyata boneka tersebut sebenamya tidak menjijikkan, lambat laun anak tersebut tidak jijik lagi kepada boneka. Peletakan permainan yang paling disukai tersebut dapat dilakukan secara berulang-ulang.

b) Metode membosankan. Misalnya saja anak kecil suka mengisap rokok. Ia disuruh merokok terus sampai bosan; dan setelah bosan, ia akan berhenti merokok dengan sendirinya.

c) Metode mengubah lingkungan. Jika anak bosan belajar, maka lingkungan belajarnya dapat diubah-ubah sehingga ada suasana lain dan memungkinkan ia betah belajar. 
Dalam jiwa manusia terdapat berbagai macam daya. Daya-daya yang mempunyai peranan yang sangat penting dalam jiwa manusia ialah; pengamatan, tanggapan, ingat, fantasi, berpikir, perasaan dan kemauan.

Dalam kegiatan belajar mengajar siswa menggunakan daya yang berada dalam jiwanya untuk berusaha memahami isi pelajaran yang disampaikan oleh guru. Usaha siswa dalam memahami pelajaran ini menimbulkan istilah baru yang diangkat dalam skripsi ini, mengenai usaha siswa dalam memahami isi pelajaran. Usaha memahami ini disebut sebagai daya serap siswa.

Daya, menurut ahli-ahli ilmu jiwa Daya mengemukakan suatu teori bahwa jiwa manusia mempunyai daya-daya. Daya-daya ini adalah kekuatan yang tersedia (Djamarah, 2002:17). Hal ini sangat beralasan karena para ahli dari aliran psikologi daya ini memikirkan jiwa dianalogikan dengan raga (jasmani) itu mempunyai tenaga atau daya, maka jiwa juga dianggap mempunyai daya-daya (Suryabrata, 1998:224).

Tingkat daya serap belajar siswa bermacam-macam yaitu terdapat siswa yang memiliki daya serap belajar tinggi, sedang, dan rendah. Menurut Piet A. Sahertian (1994:101) ukuran tingkat daya serap belajar siswa dapat dibedakan menjadi tiga hal sebagai berikut:

a. Siswa yang maju

b. Siswa yang cukup

a. Siswa yang kurang

Pengertian daya pengamatan adalah daya jiwa yang memasukkan kesan dari luar melalui dengan menggunakan alat dria. Ada empat faktor yang memungkinkan terjadinya suatu pengamatan. Perangsang (stimulus-benda yang diamati), alat indera- otak- dan perhatian. Sedangkan daya ingat yaitu daya untuk menyimpan dan mengeluarkan kesan-kesan (Purwantoro, 1990:36-37).

Syarat belajar dengan baik apabila alat-alat tersebut dalam kondisi yang baik pula. Seperti yang diungkapkan oleh Arifin bahwa kemampuan belajar manusia sangatlah berkaitan dengan kemampuan manusia untuk mengetahui dan mengenal terhadap objek-objek pengamatan melalui panca inderanya (Arifin, 1993:71).

\section{Metode Penelitian}

Penelitian ini dilaksanakan di SMP Negeri 6 Kota Palopo yang dilakukan pada semester genap tahun pelajaran 2018/2019 yaitu pada bulan April sampai dengan bulan Juni 2019. Jenis penelitian ini adalah penelitian eksperimen.

Satuan eksperimen dalam penelitian ini adalah siswa kelas VIII SMP Negeri 6 Palopo tahun pelajaran 2018/2019. Pemilihan kelas eksperimen dalam penelitian ini dilakukan dengan menggunakan Random Sampling. Perlakuan yang diberikan yaitu metode stimulus respon. Untuk pertemuan pertama, kelas eksperimen diberikan pretest untuk mengetahui kemampuan awal siswa. Kemudian perlakuan (treatment) diberikan pada kelas eksperimen yang diajar 
dengan menggunakan metode stimulus respon. Untuk mengetahui daya serap pada pembelajaran keterampilan berbicara siswa maka diberikan posttest.

Dalam penelitian ini, Pengumpulan data untuk hasil daya serap siswa dilakukan dengan dua tahap. Tahap pertama yaitu pemberian tes awal. Tes awal diberikan pada saat pertemuan pertama. Tahap kedua yaitu pemberian tes akhir (posttest). Hasil dari pretest maupun posttest yang sudah diisi oleh siswa diperiksa jawabannya oleh peneliti. Setelah perhitungan selesai, maka hasil dari perhitungan itu adalah nilai yang diperoleh oleh masing-masing siswa.

\section{Hasil Penelitian}

a. Data Hasil Daya Serap pada Pembelajaran Keterampilan Berbicara Siswa Kelas VIII SMP Negeri 6 Palopo Sebelum dan Setelah Diterapkan Metode Stimulus Respon.

Berikut ini adalah tabel yang berisi tentang gambaran umum skor hasil daya serap pada pembelajaran keterampilan berbicara siswa sebelum dan setelah diajar dengan menggunakan metode stimulus respon yang diperoleh dari data hasil pretest dan posttest.

Tabel 1. Statistik Deskriptif Hasil Daya Serap pada Pembelajaran Keterampilan Berbicara Siswa Sebelum dan Setelah Diterapkan Metode Stimulus Respon

\begin{tabular}{lrc}
\hline \multirow{2}{*}{ Statistik } & \multicolumn{2}{c}{ Nilai Statistik } \\
\cline { 2 - 3 } & Pretest & Postest \\
\hline Ukuran sampel & 32,00 & 32,00 \\
Nilai maksimum & 25,00 & 100,00 \\
Nilai minimum & 10,00 & 62,00 \\
Nilai rata-rata & 20,25 & 87,38 \\
Deviasi standar & 3,20 & 9,83 \\
Variansi & 10,26 & 96,57 \\
\hline
\end{tabular}

Berdasarkan tabel 1 data hasil daya serap pada pembelajaran keterampilan berbicara siswa pada pretest terlihat bahwa nilai rata-rata 20,25 sedangkan pada posttest terlihat bahwa nilai rata-rata 87,38. Secara deskriptif dapat dikatakan bahwa daya serap siswa kelas VIII SMP Negeri 6 Palopo menjadi lebih baik dari pada sebelum diberikan pembelajaran dengan menggunakan metode stimulus respon.

Besarnya peningkatan hasil daya serap pada pembelajaran keterampilan berbicara siswa yang diajar dengan menggunakan metode stimulus respon yang dihitung dengan rumus gain ternormalisasi dapat dilihat pada tabel 2 .

Tabel 2. Klasifikasi Gain Ternormalisasi 


\begin{tabular}{cccc}
\hline $\begin{array}{c}\text { Koefisien normalisasi } \\
\text { gain }\end{array}$ & Klasifikasi & Frekuensi & Persentase (\%) \\
\hline $\mathrm{g}<0,3$ & Rendah & 0 & 0 \\
$0,3 \leq \mathrm{g}<0,7$ & Sedang & 5 & 15,62 \\
$\mathrm{~g} \geq 0,7$ & Tinggi & 27 & 84,38 \\
\hline Jumlah & & 32 & 100 \\
\hline Rata-rata & 0,84 & \multicolumn{2}{c}{ Tinggi } \\
\hline
\end{tabular}

Sumber: Hasil Analisis Data Primer (2019)

Berdasarkan tabel di atas diperoleh keterangan peningkatan daya serap pada pembelajaran siswa setelah diterapkannya pembelajaran dengan menggunakan metode stimulus respon. Adapun yang memperoleh peningkatan daya serap dengan kategori sedang 5 siswa dengan persentase 15,62\%. Sedangkan peningkatan daya serap dengan kategori tinggi 27 siswa dengan persentase $84,38 \%$.

Berdasarkan nilai rata-rata pretest dan posttest siswa pada tabel 2 maka peningkatan daya serap siswa pada pembelajaran keterampilan berbicara yang diajar dengan menggunakan metode stimulus respon berada pada kategori tinggi.

1) Hasil Daya Serap pada Pembelajaran Keterampilan Berbicara Siswa Sebelum Diterapkan Metode Stimulus Respon

Hasil analisis statistik deskriptif berkaitan dengan skor variabel hasil daya serap pada pembelajaran keterampilan berbicara siswa sebelum diajar dengan menggunakan metode stimulus respon disajikan dalam tabel 3.

Tabel 3. Statistik Deskriptif Hasil Daya Serap pada Pembelajaran Keterampilan Berbicara Siswa Kelas VIIIв SMP Negeri 6 Palopo Sebelum Diterapkan Metode Stimulus Respon

\begin{tabular}{lc}
\hline Statistik & Nilai Statistik \\
\hline Ukuran sampel & 32,00 \\
Rata-rata & 20,25 \\
Nilai Tengah & 21,00 \\
Standar Deviasi & 3,20 \\
Variansi & 10,26
\end{tabular}

Sumber: Hasil Analisis Data Primer (2019)

Berdasarkan tabel 3 nilai tertinggi yang diperoleh siswa adalah 25, nilai terendah 10, dengan rentang skor 15 . Jika skor hasil daya serap pada pembelajaran keterampilan berbicara siswa kelas VIIIв SMP Negeri 6 Palopo sebelum diterapkan metode stimulus respon dikelompokkan dalam lima kategori menurut Nurkancana (Nurhida, 2015:49), maka diperoleh tabel distribusi frekuensi dan presentase hasil daya serap pada pembelajaran keterampilan berbicara seperti ditunjukkan pada tabel berikut ini. 
Tabel 4. Distribusi Frekuensi Hasil Daya Serap pada Pembelajaran Keterampilan Berbicara Siswa Kelas VIIIв SMP Negeri 6 Palopo Sebelum Diterapkan Metode Stimulus Respon

\begin{tabular}{cccc}
\hline Statistik & Kategori & Frekuensi & Persentase (\%) \\
\hline $0-54$ & Sangat & 32 & 100 \\
$55-64$ & rendah & 0 & 0 \\
$65-79$ & Rendah & 0 & 0 \\
$80-89$ & Sedang & 0 & 0 \\
$90-100$ & Tinggi & 0 & \\
\hline Jumlah & Sangat tinggi & 32 & 100 \\
\hline
\end{tabular}

Sumber: Hasil Analisis Data Primer (2019)

Dari tabel di atas menunjukkan bahwa dari 32 siswa kelas VIIIB SMP Negeri 4 Palopo yang menjadi sampel pada penelitian (pretest) hasil daya serap pada pembelajaran keterampilan berbicara sebelum diajar dengan metode stimulus respon berada pada kategori sangat rendah.

2) Hasil Daya Serap pada Pembelajaran Keterampilan Berbicara Siswa Setelah Diterapkan Metode Stimulus Respon

Hasil analisis statistika deskriptif berkaitan dengan skor variabel hasil daya serap pada pembelajaran keterampilan berbicara siswa setelah diterapkan metode stimulus respon disajikan dalam tabel 5 berikut.

Tabel 5. Statistik Deskriptif Hasil Daya Serap pada Pembelajaran Keterampilan Berbicra Siswa VIII SMP Negeri 6 Palopo Setelah Diterapkan Metode Stimulus Respon

\begin{tabular}{lc}
\hline Statistik & Nilai Statistik \\
\hline Ukuran sampel & 32,00 \\
Nilai rata-rata & 87,38 \\
Nilai tengah & 89,50 \\
Deviasi standar & 9,83 \\
Variansi & 96,57
\end{tabular}

Sumber: Hasil Anaisis Data Primer (2019)

Berdasarkan tabel 5 nilai tertinggi yang diperoleh siswa adalah 100, nilai terendah 62 dengan rentang nilai 38. Jika skor hasil daya serap pada pembelajaran

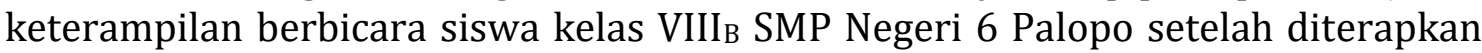
metode stimulus respon dikelompokkan dalam lima kategori menurut Nurkancana (Nurhida, 2015:49), maka diperoleh tabel distribusi frekuensi dan persentase hasil daya serap pada pembelajaran keterampilan berbicara seperti ditunjukkan pada tabel berikut ini. 
Tabel 6. Distribusi Frekuensi Hasil Daya Serap pada Pembelajaran Keterampilan Berbicara Siswa Kelas VIIIB SMP Negeri 6 Palopo Setelah Diterapkan Metode Stimulus Respon

\begin{tabular}{clcc}
\hline Statistik & Kategori & Frekuensi & Persentase (\%) \\
\hline $0-54$ & Sangat rendah & 0 & 0 \\
$55-64$ & Rendah & 1 & 3,12 \\
$65-79$ & Sedang & 6 & 18,75 \\
$80-89$ & Tinggi & 9 & 28,13 \\
$90-100$ & Sangat tinggi & 16 & 50 \\
\hline Jumlah & & 32 & 100 \\
\hline
\end{tabular}

Sumber: Hasil Analisis Data Primer (2019)

Tabel 6 menunjukkan bahwa dari 32 siswa kelas VIII SMP Negeri 6 Palopo yang menjadi sampel pada penelitian (posttest) hasil daya serap pada pembelajaran keterampilan berbicara dengan metode stimulus respon. Siswa yang dikategorikan sangat tinggi 16 siswa (50\%), 9 siswa (28,13\%) yang dikategorikan tinggi, 6 siswa $(18,75 \%)$ yang dikategorikan sedang, 1 siswa $(3,12 \%)$ yang berkategori rendah, dan tidak ada (0\%) yang dikategorikan sangat rendah. Hal ini berarti bahwa hasil daya serap pada pembelajaran keterampilan berbicara dari 32 siswa pada VIIIв SMP Negeri 6 Palopo yang diukur dari hasil tes setelah melakukan pembelajaran dengan metode stimulus respon dapat dikategorikan bahwa yang berkategori sedang $18,75 \%$, jumlah siswa yang berkategori sangat tinggi dengan persentase $50 \%$, yang berkategori tinggi yaitu $28,13 \%$, yang berkategori rendah dengan presentase $3,12 \%$, dan untuk yang berkategori sangat rendah tidak ada (0\%). Artinya dari 32 siswa setelah dilaksanakan metode stimulus respon, ada 28 siswa mencapai ketuntasan belajar, 6 siswa berada pada kategori sedang, 9 siswa berada pada kategori tinggi, dan 16 siswa berada pada kategori sangat tinggi. Secara umum hasil daya serap pada pembelajaran keterampilan berbicara siswa berada pada kategori sangat tinggi.

b. Ketuntasan Belajar Siswa Sebelum dan Sesudah Diterapkan Metode Stimulus Respon

Berdasarkan kriteria ketuntasan minimal (KKM) yang berlaku di SMP Negeri 6 Palopo yang digunakan untuk menentukan tingkat pencapaian ketuntasan hasil daya serap siswa, maka banyaknya siswa yang tuntas dan belum tuntas dapat dilihat pada tabel 7 berikut.

Tabel 7. Distribusi Ketuntasan Hasil Belajar Siswa

\begin{tabular}{|c|c|c|c|c|c|}
\hline \multirow[b]{2}{*}{ Interval } & \multirow{2}{*}{$\begin{array}{l}\text { Kategori } \\
\text { Ketuntasan }\end{array}$} & \multicolumn{2}{|c|}{ Pretest } & \multicolumn{2}{|c|}{ Posttest } \\
\hline & & Frekuensi & Persentase(\%) & Frekuensi & Persentase \\
\hline$<65$ & tidak tuntas & 32 & 100 & 4 & 12,5 \\
\hline$\geq 65$ & Tuntas & 0 & 0 & 28 & 87,5 \\
\hline
\end{tabular}

Sumber: Hasil Analisis Data Primer (2019) 
Tabel 7 di atas menunjukkan bahwa persentase siswa yang tuntas secara klasikal sebesar 87,5\%, dimana suatu kelas dikatakan tuntas belajarnya (ketuntasan klasikal) jika dalam kelas tersebut terdapat $\geq 85 \%$ siswa yang telah tuntas belajarnya. Berdasarkan uraian di atas, dapat disimpulkan bahwa metode stimulus respon pada pembelajaran keterampilan berbicara berpengaruh terhadap daya serap siswa kelas VIIIB SMP Negeri 6 Palopo.

\section{Simpulan}

Berdasarkan hasil analisis data yang telah dilakukan dapat ditarik beberapa kesimpulan sebagai berikut:

1. Hasil daya serap siswa kelas VIII SMP Negeri 6 Palopo sebelum diterapkan metode stimulus respon pada pembelajaran keterampilan berbicara berada pada kategori sangat rendah.

2. Hasil daya serap siswa kelas VIII SMP Negeri 6 Palopo setelah diterapkan metode stimulus respon pada pembelajaran keterampilan berbicara berada pada kategori sangat tinggi.

3. Terjadi peningkatan daya serap siswa kelas VIII SMP Negeri 6 Palopo setelah penerapan metode Stimulus Respon pada pembelajaran keterampilan berbicara. 


\section{Daftar Pustaka}

Alwi, Hasan, dkk. 2008. Kamus Besar Bahasa Indonesia Edisi Keempat. Jakarta: Balai Pustaka.

Akhadiat, Sabarti. dkk. 1996. Pembinaan Kemampuan Menulis Bahasa Indonesia. Jakarta: IKAPI.

Haduyanto. 2001. Membudayakan Kebiasaan Menulis. Sebuah Pengantar. Jakarta: PT. Fikahati Aneska

Keraf, Goris. 1994. Komposisi. Jakarta: Nusa Indah

Kusumah, Encep, dkk. 2003. Menulis 2. Jakarta: Pusat Penerbitan Univeritas Terbuka.

Kusnandar. 2008. Penelitian Tindakan Kelas. Jakarta: Rajawali Pers.

Liang Gie, The. 2002. Terampil Mengarang. Yogyakarta: Andi.

Melki. 2011. Peningkatan Kemampuan Menulis Ringkasan dengan Metode Pembelajaran Kooperatif Tipe CIRC pada Siswa Kelas XI IPA 1 SMA Negeri 1 Baebunta Kabupaten Luwu Utara: Skripsi.Makassar: UNM.

Solihatin, Etin. 2007. Cooperative Learning. Jakarta: Bumi Aksara

Sugiyono. 2012. Metode Penelitian Kuantitatif kualitatif dan R\&D. Bandung: Alfabeta

Tarigan, Hendry Guntur. 2008. Menulis sebagai Keterampilan Berbahasa. Bandung: Angkasa.

Wardhani, IGAK. 2008. Penelitian Tindakan Kelas. Jakarta: Universitas Terbuka. Yunus, Mohammad \& Suparno. 2007. Keterampilan Menulis. Jakarta: Universitas Terbuka 